Pak. j. sci. ind. res. Ser. B: biol. sci. 2021 64B(3) 263-273

\title{
Agar Extraction, Physical Properties, FTIR Analysis and Biochemical Composition of Three Edible Species of Red Seaweeds Gracilaria corticata (J. Agardh), Gracilaria dentata (J. Agardh) and Gracilariopsis longissima (S. G. Gmelin) Steentoft, L. M; Irvine and Farnham
}

\author{
Rashida Qari ${ }^{\mathrm{a} *}$ and Saima Haider ${ }^{\mathrm{b}}$ \\ ${ }^{a}$ School of Maritime Sciences, Bahria University, Karachi Campus, Karachi, Pakistan \\ ${ }^{b}$ Institute of Marine Sciences, University Campus of Karachi, Pakistan, Pakistan
}

(received January 23, 2019; revised June 2, 2019; accepted August 7, 2019)

\begin{abstract}
Three species of red algae Gracilaria corticata (J. Agardh), Gracilaria dentata (J. Agardh) and Gracilariopsis longissima (S.G. Gmelin), Steentoft, L. M; Irvine and Farnham (formerly Gracilaria verrucosa (Hudson) were collected from four different sites (Buleji, Hawks Bay, Manora and Paradise Point) of Karachi coast. The G. corticata was the dominant species and the highest yield of agar was compared to other studied species. The physical properties such as gel temperature, melting temperature, density, viscosity and gel strength showed large variations. Interestingly, the gel temperature, melting temperature, density, and gel strength had the highest value in G. corticata samples collected, while gel viscosity recorded the highest value in $G$. dentata samples. Intensive spectroscopic FTIR analysis was determined in all three species of $G$. corticata, $G$. dentata and $G$. longissima. The bands at $414.7 / \mathrm{cm}$ to $3917.2 / \mathrm{cm}$ represents stretching and bending vibrations of alcohol O-H, amine $\mathrm{N}-\mathrm{H}$, alkane $\mathrm{C}-\mathrm{H}$, alkyne $\mathrm{C}=\mathrm{C}$, nitriles $\mathrm{C}=\mathrm{N}$, carboxyl $\mathrm{C}=\mathrm{O}$, nitro aromatic $\mathrm{N}=\mathrm{O}$, alkane $\mathrm{C}-\mathrm{C}$, nitro methane $\mathrm{C}-\mathrm{N}$, aliphatic amines $\mathrm{C}-\mathrm{N}$, sulfoxides $\mathrm{S}=\mathrm{O}$, alkene $\mathrm{C}-\mathrm{H}$ alkyl halide $\mathrm{C}-\mathrm{Cl}$, C-I groups. The ash content of all studied species (G. corticata, G. dentata and G. longissima) was in the range of $20-30 \%$, while the carbohydrate content was in the range of $22-24 \%$. The results of this study suggested the utilization of our natural resources present in Karachi coast. This could be achieved by determining the quantity and quality of agar in the edible species of Gracilaria/Gracilariopsis.
\end{abstract}

Keywords: agar yield, gel properties, seaweed, FTIR, Karachi coast

\section{Introduction}

Agar is a water-soluble gel-forming polysaccharide extracted from agarophyte members of Rhodophyta composed of mainly two sugar residues, D-galactose (51-53\%) and 3,6 anhydro-galactose (46\%). It is also composed of small proportions of monosaccharides and substituent groups known as disaccharide of hydroxyl groups with sulfate hemiesters and methyl ethers hemiesters and methyl ethers in various combination and more rarely with a cyclic pyruvate ketal as 4,6 O[(R)-1-carboxyethylidene] acetal $\mathrm{R}_{2} \mathrm{C}\left(\mathrm{OR}^{\prime}\right)^{2}$ (Cynthia Layse et al., 2011; Israel et al., 2010; Praiboon et al., 2006; Qari and Siddiqui, 1993). Gracilaria is the third largest genus in Rhodophyta, with more than 300 species, of which 180 species were accepted taxonomically (Sahu and Sahoo, 2013). The distributions of Gracilaria species is cosmopolitan and are commercially important in the production of phyco-colloid agar. The world*Author for correspondence; E-mail: rqari2002@yahoo.com wide production of agar was 9600 tonnes valued at US \$ 173 million in 2009, while China, Chile and Indonesia were the main producers (Bixler and Porse, 2010).

Gracilaria corticata, Gracilaria dentata and Gracilariopsis longissima species of Gracilaria/Gracilariopsis are mainly used for making food grade agar. They are utilized as human food, mostly in salads and soups, as feed for many animals, as potential source for nutrient removal for waste water treatment and as biomass for energy generation (Sahu and Sahoo, 2013). He was evaluated potential growth rates and dry weight yields of numerous species of red seaweeds. The genus Gracilaria is considered as the most attractive candidate because of its ability to achieve high yields and produce commercially valuable extracts (Cynthia Layse et al., 2011).

Gracilaria species are important for industrial and bio-technological use because they have phycocolloid, the main source of agar $\alpha-(1,4)-3,6$-anhydro-L-galactose 
and B-(1,3)-D-galactose with little esterification in cell wall (Cynthia et al., 2011). These species also produce acrylic acid which acts as an important bioactive metabolites with antibiotic activity. Major lipids such as prostaglandins are abundant in this genus. Variety of lactones are also found in Gracilaria from the Pacific Ocean such as, aplysia toxin isolated from Gracilariopsis longissima (S.G. Gmelin) Steentoft, L.M. Irvine and Farnham (Cynthia et al., 2011). Other constituents are also contained in this genus such as proteins r-phycoerythrin from Gracilaria longa and "Gigartinine" (new amino acid) from Agarophyton chilense (C. J. Bird, McLachlan, E. C. Oliveira) Gurgel, J. N. Norris, Fredericq (formerly Gracilaria chilensis) (Wilcox et al., 2001).

Physical and chemical characterization of agar polysaccharides extracted from the Thai and Japanese species of Gracilaria have been studied (Praiboon et al., 2006). The morphology and agar contents in some important Gracilaria species of Indian coasts have also been demonstrated by Sahu and Sahoo (2013). Given the fact that the yield and physical properties of agar such as gelling temperature, gel melting point, gel strength as well as its chemical properties determine its value to the industry (Praiboon et al., 2006), studies have been conducted on the properties and seasonal variations of agar yield in Gracilaria sp. (Whyte et al., 1981). In view of these, this present study was conducted to investigate the quantity and quality of agar in the three edible species of Gracilaria found in Karachi coast of Pakistan. Fourier transform infrared spectroscopy was used in this study owing to the fact that this technique is efficient and flexible in use for analyzing phycocolloid extracted from marine plants.

Researches on the distribution and morpho-ecological of marine benthic algae along the coast of Balochistan, Pakistan (Shameel et al., 2000) as well as biochemical composition and yield of agar from the Gracilaria corticata of Karachi coast (Qari and Siddiqui, 1993) have been demonstrated to the best of our knowledge, there is paucity of information on the analysis of agar polysaccharides from FTIR technique in Pakistan. The present study constitute a first approach for utilizing Gracilaria red algae species (Gracilaria corticata, Gracilaria dentata and Gracilariopsis longissima) as an industrial source of raw material for agar extraction in Pakistan.

\section{Material and Methods}

The monthly fresh samples of Gracilaria species (G. corticata, G. dentata and G. longissima) were collected $(\mathrm{n}=86)$ at different periods on monthly variation from four different exposed sites of Karachi coast at low tide. During the experimental period, samples collected came from Buleji $(\mathrm{n}=33)$, Hawks Bay $(\mathrm{n}=8)$, Manora $(\mathrm{n}=$ 23) and Paradise point $(\mathrm{n}=22)$ G. corticata $(\mathrm{n}=44)$ was collected from Buleji, Hawks Bay, Manora and Paradise point, $G$. dentata $(\mathrm{n}=21)$ from Buleji and Manora and G. longissima $(\mathrm{n}=21)$ from Buleji and Paradise point at different periods of 2014-2016. All the samples collected were separately placed in prelabeled plastic bags and brought to the laboratory, carefully cleaned from mud debris and other epiphytes with filtered seawater.

The agar extraction and its physical properties: gelation temperature, melting point, relative density, viscosity and strength were determined by the method of Whyte and Engler (1980). Mohan (2005) method was used for the FTIR analysis of agar samples. The fresh potassium bromide ( $\mathrm{KBr}$ ) crystals (Ft-IR grade) were grinded in mortar using pestle into a fine powder and kept in desiccators. The extracted agar samples were grinded in separate mortar pestle to make an homogenous mixture of sample mixed with $\mathrm{KBr}$ powder (1:10). After mixing the powders tablet was made by potassium bromide tablet dye and press at a pressure $<4$ ton-ram area. The tablet or disc placed in the sample holder and FTIR spectra were recorded in the range of 4000-400 $\mathrm{cm}^{-1}$ on FTIR spectrophotometer (Bruker Vector-22). The carbohydrate content was estimated by using phenol sulfuric acid method (Dubois et al., 1956). Ash or total inorganic content was determined by the standard method of AOAC (1990). The total organic content was determined by calculating the difference between the inorganic content and total content.

\section{Results and Discussion}

The present data reveals high variability in the agar content in all the three species, sampling sites and collection time (Fig. 1-3). The concentration of agar increased in March and May and start decreasing from June to August (Fig. 1). The high agar concentration was mostly found in winter season. The highest agar content was obtained from Buleji samples as compared to other three experimental sites (Fig. 2) The study reported highest agar extracted from Gracilaria 
longissima (13-56\%) with mean concentration value of $27.20 \%$. as compared to other two species G. corticata and G. dentata (Fig. 3).

G. corticata was found throughout the year at Buleji, Manora and Paradise point except during the months of April, August, September and November when samples were not found at Hawks Bay. The agar content of G. corticata which varied throughout the years had a range of $14-42 \%$ with mean concentration value of $25.09 \%$. Samples collected in Buleji were high in

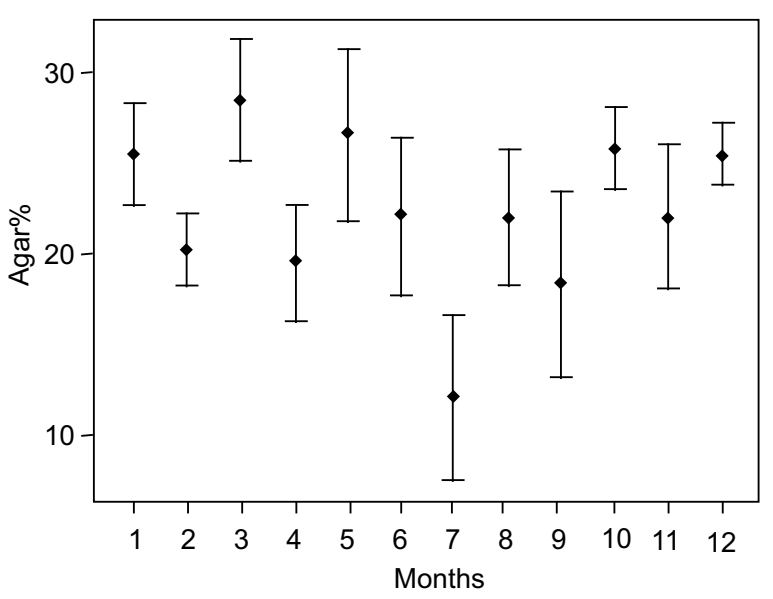

Fig. 1. Monthly variation in agar content (\% dry wt.) of G. corticata, G. dentata and G. longissima collecting from different sites of Karachi coast.

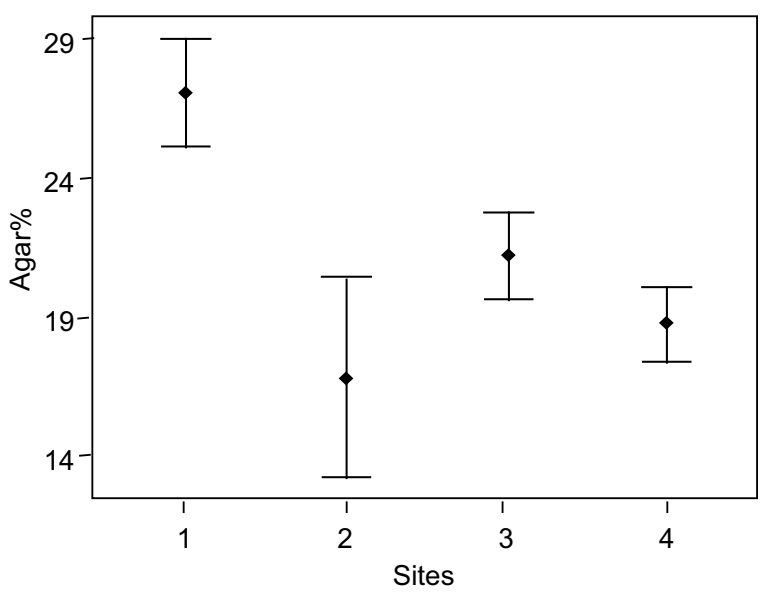

Fig. 2. Variation in agar content (\% dry wt.) of G. corticata, G. dentata and G. longissima collecting from different sites (Buleji, Hawks Bay, Manora and Paradise Point) of Karachi coast.
September (42\%), while it was also high in Hawks Bay sample (33\%) in October (Fig. 4). Samples collected in Manora recorded high value in January and September (28.8 and 28.66\%) respectively, while those collected in Paradise Point recorded high value (30\%) in January (Fig. 4). G. dentata that was collected from major two sites (Buleji and Manora) was not found at Buleji in June and July but was absent only in July at Manora site. The range of agar content in G. dentata was 10$40 \%$ with mean concentration value of $21.79 \%$. Samples collected in Buleji recorded high values of agar concentration in November (40\%), while those collected in Manora recorded high value $(30 \%)$ in December (Fig. 5). G. longissima was also collected from two sites (i.e., Buleji and Paradise point) throughout the year except during the months of July at Buleji and July and September at Paradise Point. The range of agar content in $G$. longissima was $13-56 \%$ with mean concentration value of $27.20 \%$. The agar concentration was high in May in both Buleji and Paradise point samples (56 and 30\%), respectively (Fig. 6).

The density of agar extract in G. corticata was in a range of $0.79-1.71 \mathrm{~g} / \mathrm{cm}^{3}$ in all sample sites. This study recorded high density of agar extract of G. corticata in both Buleji and Paradise Point in September $\left(1.71 \mathrm{~g} / \mathrm{cm}^{3}\right.$ and $1.03 \mathrm{~g} / \mathrm{cm}^{3}$ ), respectively. Samples collected in Hawks Bay recorded high value in October $\left(1.55 \mathrm{~g} / \mathrm{cm}^{3}\right)$ while those sampled in Manora recorded high value $\left(1.04 \mathrm{~g} / \mathrm{cm}^{3}\right)$ in January (Table 1$)$. The density of agar extract in G. dentata was in a range of $0.39-1.63 \mathrm{~g} / \mathrm{cm}^{3}$.

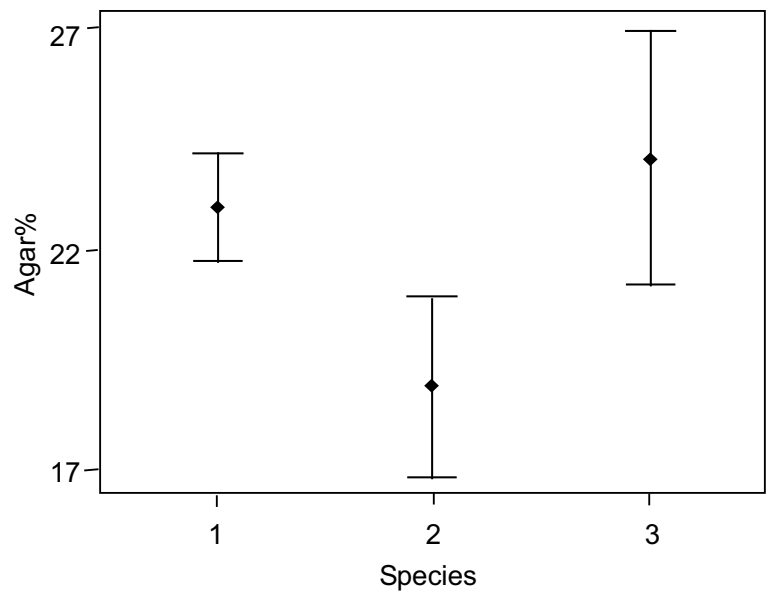

Fig. 3. Variation in agar content ( $\%$ dry wt.) of G. corticata, G. dentata and G. longissima collecting from different sites of Karachi coast. 


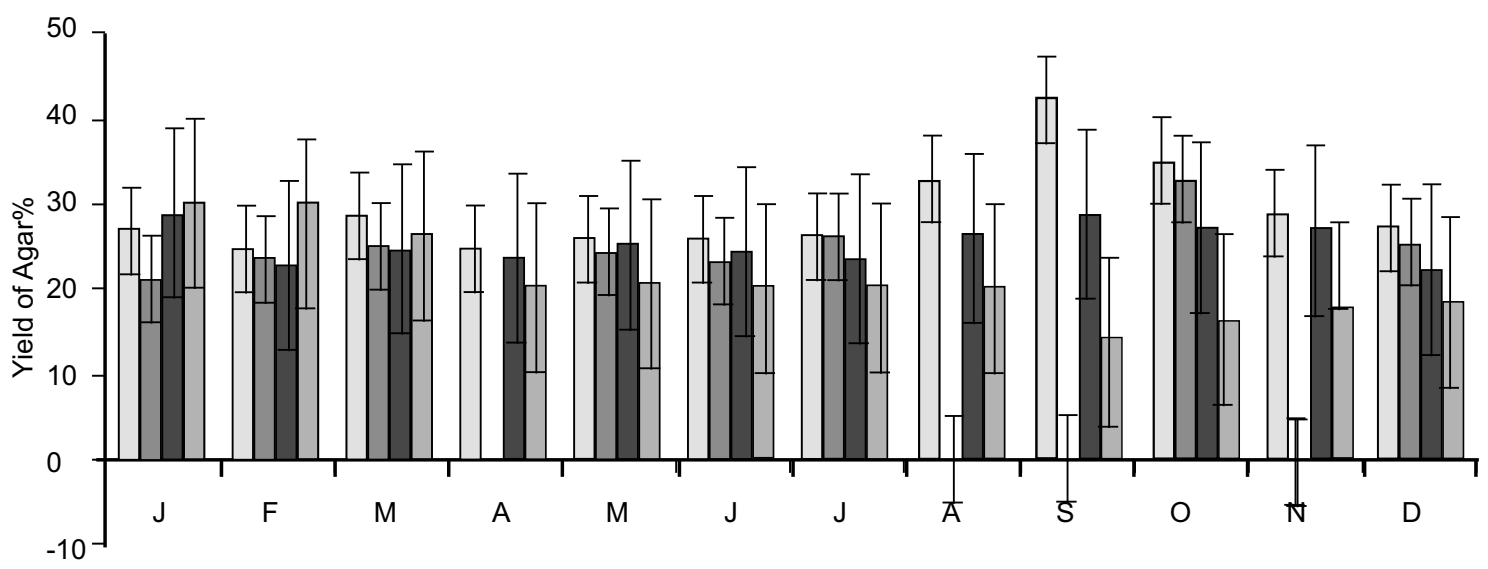

$\square$ Bulegi $\square$ Hawks Bay $\square$ Manora $\square$ Paradise point

Fig. 4. Seasonal variations in the yield of agar from G. corticata collecting from different sites of Karachi coast.

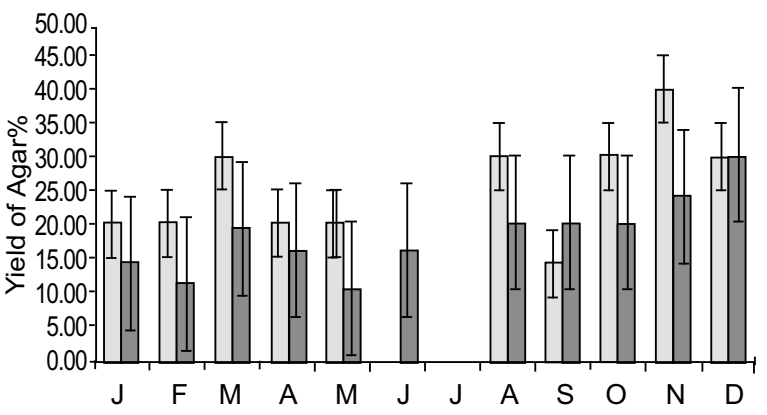

$\square$ Bulegi $\square$ Manora

Fig. 5. Seasonal variations in the yield of agar from $G$. dentata collecting from different sites of Karachi coast.

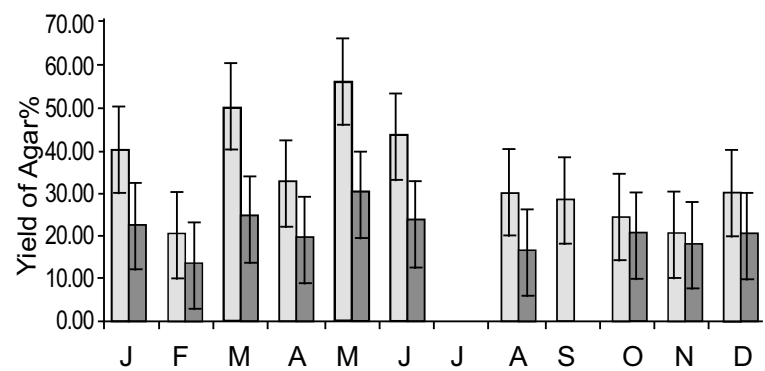

Bulegi $\square$ Paradise point

Fig. 6. Seasonal variations in the yield of agar from $G$. longissima collecting from different sites of Karachi coast.

Table 1. Gel density $\left(\mathrm{g} / \mathrm{cm}^{3}\right)$ of agar extracted from G. corticata, G. dentata and G. longissima collected from different sites of Karachi coast

\begin{tabular}{|c|c|c|c|c|c|c|c|c|}
\hline \multirow{2}{*}{$\begin{array}{l}\text { Species } \\
\text { sites }\end{array}$} & \multicolumn{4}{|c|}{ G. corticata } & \multicolumn{2}{|c|}{ G. dentata } & \multicolumn{2}{|c|}{ G. longissima } \\
\hline & Buleji & Hawks bay & Manora & Paradise point & Buleji & Manora & Buleji & Paradise point \\
\hline $\mathrm{J}$ & 1.09 & 1.00 & 1.04 & 0.97 & 0.81 & 0.50 & 1.62 & 0.71 \\
\hline $\mathrm{F}$ & 0.99 & 1.10 & 0.81 & 0.89 & 0.81 & 0.39 & 0.8 & 0.42 \\
\hline M & 1.15 & 1.18 & 0.88 & 0.84 & 1.21 & 0.68 & 2.02 & 0.77 \\
\hline A & 1.00 & 0.00 & 0.84 & 0.84 & 0.81 & 0.57 & 1.29 & 0.61 \\
\hline M & 1.04 & 1.14 & 0.91 & 0.90 & 0.81 & 0.36 & 2.26 & 0.97 \\
\hline $\mathrm{J}$ & 1.04 & 1.09 & 0.88 & 0.87 & 0.00 & 0.57 & 1.74 & 0.74 \\
\hline $\mathrm{J}$ & 1.05 & 1.22 & 0.86 & 0.85 & 0.00 & 0.00 & 0.00 & 0.00 \\
\hline A & 1.34 & 0.00 & 0.94 & 0.93 & 1.22 & 0.71 & 1.21 & 0.51 \\
\hline $\mathrm{S}$ & 1.71 & 0.00 & 1.02 & 1.03 & 0.57 & 0.72 & 1.14 & 0.00 \\
\hline $\mathrm{O}$ & 1.42 & 1.55 & 0.98 & 0.97 & 1.22 & 0.72 & 0.97 & 0.64 \\
\hline $\mathrm{N}$ & 1.17 & 0.00 & 0.96 & 0.96 & 1.63 & 0.86 & 0.81 & 0.58 \\
\hline $\mathrm{D}$ & 1.11 & 1.19 & 0.79 & 0.79 & 1.22 & 1.07 & 1.21 & 0.64 \\
\hline
\end{tabular}


High density of agar extract was recorded in Buleji sites in the month of November $\left(1.63 \mathrm{~g} / \mathrm{cm}^{3}\right)$, while high value was also recorded in Manora in December (1.07 $\left.\mathrm{g} / \mathrm{cm}^{3}\right)$. The agar extract of $G$. longissima had density which ranged between $0.42-2.26 \mathrm{~g} / \mathrm{cm}^{3}$ with high values at Buleji and Paradise Point in May (2.26 and 0.97 $\mathrm{g} / \mathrm{cm}^{3}$ ) respectively (Table 1 ).

The gel viscosity of G. corticata agar extract was in the range of 39-92 cP. In Buleji samples viscosity of agar was high in September (87 cP) and in Hawks Bay samples it was high $(92 \mathrm{cP})$ in October whereas in both Manora and Paradise samples gel viscosity was high in January $80 \mathrm{cP}$ and $83 \mathrm{cP}$ respectively (Table 2 ). In
G. dentata sample gel viscosity of agar extract was in the range of $28-83 \mathrm{cP}$. In both Buleji and Manora samples viscosity was high $(83 \mathrm{cP})$ in November and December respectively (Table 2). The gel viscosity of G. longissima agar extracts was in range of 36-116 cP. In both Buleji and Paradise point, it was high in May $116 \mathrm{cP}$ and 83 cP respectively (Table 2 ).

Gel temperature of $G$. corticata was in the ranged of 24-85 ${ }^{\circ}$ C. In Buleji, G. corticata samples gel temperature was high in September $\left(76^{\circ} \mathrm{C}\right)$, October $\left(85^{\circ} \mathrm{C}\right)$ in Hawks Bay samples collected, and January in samples collected at both Manora and Paradise Point samples $\left(56\right.$ and $52^{\circ} \mathrm{C}$ ) respectively (Table 3 ). The gel tem-

Table 2. Gel viscosity (cP) of agar extracted from G. corticata, G. dentata and G. longissima collected from different sites of Karachi coast

\begin{tabular}{|c|c|c|c|c|c|c|c|c|}
\hline \multirow{2}{*}{$\begin{array}{l}\text { Species } \\
\text { sites }\end{array}$} & \multicolumn{4}{|c|}{ G. corticata } & \multicolumn{2}{|c|}{ G. dentata } & \multicolumn{2}{|c|}{ G. longissima } \\
\hline & Buleji & Hawks bay & Manora & Paradise point & Buleji & Manora & Buleji & Paradise point \\
\hline $\mathrm{J}$ & 56 & 59 & 80 & 83 & 41 & 39 & 82 & 61 \\
\hline $\mathrm{F}$ & 51 & 65 & 63 & 76 & 42 & 31 & 41 & 36 \\
\hline M & 59 & 69 & 68 & 72 & 62 & 53 & 104 & 66 \\
\hline A & 51 & 00 & 65 & 55 & 41 & 44 & 66 & 52 \\
\hline M & 53 & 67 & 70 & 57 & 41 & 28 & 116 & 83 \\
\hline $\mathrm{J}$ & 53 & 65 & 67 & 55 & 00 & 44 & 89 & 63 \\
\hline $\mathrm{J}$ & 54 & 72 & 66 & 55 & 00 & 00 & 00 & 00 \\
\hline A & 68 & 00 & 72 & 55 & 62 & 55 & 62 & 44 \\
\hline $\mathrm{S}$ & 87 & 00 & 79 & 39 & 29 & 55 & 58 & 00 \\
\hline $\mathrm{O}$ & 72 & 92 & 75 & 46 & 62 & 55 & 49 & 56 \\
\hline $\mathrm{N}$ & 60 & 00 & 74 & 50 & 83 & 66 & 42 & 50 \\
\hline D & 56 & 70 & 61 & 50 & 62 & 83 & 62 & 54 \\
\hline
\end{tabular}

Table 3. Gel boiling point $\left({ }^{\circ} \mathrm{C}\right)$ of agar extracted from $G$. corticata, G. dentata and G. longissima collected from different sites of Karachi coast

\begin{tabular}{|c|c|c|c|c|c|c|c|c|}
\hline \multirow{2}{*}{$\begin{array}{l}\text { Species } \\
\text { sites }\end{array}$} & \multicolumn{4}{|c|}{ G. corticata } & \multicolumn{2}{|c|}{ G. dentata } & \multicolumn{2}{|c|}{ G. longissima } \\
\hline & Buleji & Hawks bay & Manora & Paradise point & Buleji & Manora & Buleji & Paradise point \\
\hline $\mathrm{J}$ & 49 & 55 & 56 & 52 & 36 & 27 & 73 & 38 \\
\hline $\mathrm{F}$ & 44 & 60 & 44 & 47 & 35 & 21 & 35 & 22 \\
\hline M & 52 & 64 & 47 & 45 & 54 & 36 & 91 & 41 \\
\hline A & 45 & 0 & 45 & 34 & 36 & 30 & 58 & 51 \\
\hline M & 47 & 63 & 48 & 35 & 36 & 19 & 102 & 32 \\
\hline $\mathrm{J}$ & 47 & 60 & 47 & 34 & 0 & 31 & 78 & 39 \\
\hline $\mathrm{J}$ & 47 & 67 & 46 & 34 & 0 & 0 & 0 & 0 \\
\hline A & 60 & 0 & 50 & 34 & 54 & 38 & 54 & 27 \\
\hline $\mathrm{S}$ & 76 & 0 & 55 & 24 & 25 & 38 & 50 & 0 \\
\hline $\mathrm{O}$ & 64 & 85 & 52 & 28 & 54 & 38 & 43 & 33 \\
\hline $\mathrm{N}$ & 52 & 0 & 51 & 31 & 72 & 45 & 36 & 31 \\
\hline D & 44 & 65 & 42 & 32 & 48 & 57 & 48 & 34 \\
\hline
\end{tabular}


perature for $G$. dentata was in the ranged of $19-72^{\circ} \mathrm{C}$. In Buleji samples collected, gel temperature for G. dentata was high in November $\left(72^{\circ} \mathrm{C}\right)$ and December $\left(57^{\circ} \mathrm{C}\right)$ in Manora samples (Table 3). Gel temperature in $G$. longissima agar was in the range of $22-102{ }^{\circ} \mathrm{C}$. It was high in May $\left(102^{\circ} \mathrm{C}\right)$ in Buleji samples collected and April $\left(51^{\circ} \mathrm{C}\right)$ in Paradise Point samples (Table 3).

G. corticata gel melting point was in the ranged of $59-140{ }^{\circ} \mathrm{C}$. In Buleji samples, gel melting point was high in September $\left(133^{\circ} \mathrm{C}\right)$, October $\left(140^{\circ} \mathrm{C}\right)$ in Hawks Bay samples and January in Manora and Paradise Point samples $\left(122\right.$ and $127^{\circ} \mathrm{C}$ ) respectively (Table 4$)$. The $G$. dentata gel melting point was in the ranged of $42-126^{\circ} \mathrm{C}$ and recorded high value of $\left(126^{\circ} \mathrm{C}\right)$ in Buleji and Manora samples in November and December (Table 4). Gel melting point in G. longissima agar was

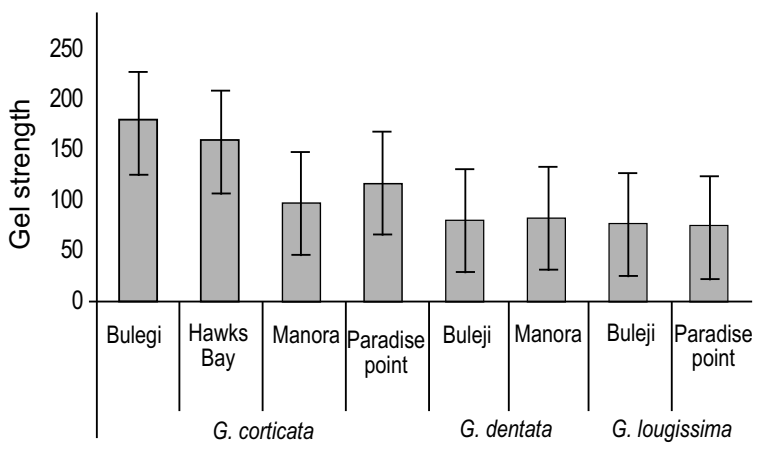

Fig. 7. Gel strength in G. corticata, G. dentata and G. longissima at different experimental sites of Karachi. in the ranged of $54-176^{\circ} \mathrm{C}$. Samples collected in Buleji recorded high value in May $\left(176^{\circ} \mathrm{C}\right)$ and those sampled in Paradise point recorded high value of $127^{\circ} \mathrm{C}$ in the month of August (Table 4).

G. corticata samples gel strength was in the ranged of 94-174 g/ $\mathrm{cm}^{2}$. The highest gel strength was found in Buleji samples $\left(174 \mathrm{~g} / \mathrm{cm}^{2}\right)$ as compared to other experimental site samples. This study observed high value of gel strength in $G$. dentata samples collected in Manora $\left(81 \mathrm{~g} / \mathrm{cm}^{2}\right)$ as compared to those collected in Buleji, while gel strength of G. longissima in Buleji samples was high $\left(74 \mathrm{~g} / \mathrm{cm}^{2}\right)$ as compared to Paradise Point samples (Fig. 7).

The results of FTIR analysis of agar extracted from G. corticata showed different peak values at 3872.8 . $3820.7,3890.2,3840.0,3789.9,3396.4$ and 2925.8 for functional groups alcohols, amines and alkanes $(\mathrm{O}-\mathrm{H}$, $\mathrm{N}-\mathrm{H}, \mathrm{C}-\mathrm{H}), 2117.7$ for alkynes and nitriles $(\mathrm{C} \equiv \mathrm{C}, \mathrm{C} \equiv \mathrm{N})$, 1645.2 and 1542.9, carbonyl amide, nitro methane and aromatic $(\mathrm{C}=\mathrm{O}, \mathrm{N}=\mathrm{O}), 1419.5$ for alkane $(\mathrm{C}-\mathrm{C}), 1323.1$ for alkane and nitro methane $(\mathrm{C}-\mathrm{N}, \mathrm{N}=\mathrm{O}), 1251.7$ aliphatic amines $(\mathrm{C}-\mathrm{N}), 1055.0$ for sulfoxides $(\mathrm{S}=\mathrm{O})$, 862.1 for alkene $(\mathrm{C}=\mathrm{H}), 769.5$ and 584.4 for alkyl halide (C-Cl), 432.0 alkyl halide (C-I) (Fig. 8 and Table 5).

G. dentata agar extract results showed different peak values at 3832.3, 3917.2, 3766.7, 3691.5, 3409.9, 2920.0, 2850.6, 2673.2 for same functional groups alcohols, amines and alkanes $(\mathrm{O}-\mathrm{H}, \mathrm{N}-\mathrm{H}, \mathrm{C}-\mathrm{H}), 2059.8$ for alkynes and nitriles $(C \equiv C, C \equiv N), 1633.6,1595$ and 1575.7 for carbonyl amide, nitro and aromatic $(\mathrm{C}=\mathrm{O}, \mathrm{N}=\mathrm{O}), 1465.8$

Table 4. Gel melting point $\left({ }^{\circ} \mathrm{C}\right)$ of agar extracted from G. corticata, G. dentata and G. longissima collected from different sites of Karachi coast

\begin{tabular}{|c|c|c|c|c|c|c|c|c|}
\hline \multirow{2}{*}{$\begin{array}{l}\text { Species } \\
\text { sites }\end{array}$} & \multicolumn{4}{|c|}{ G. corticata } & \multicolumn{2}{|c|}{ G. dentata } & \multicolumn{2}{|c|}{ G. longissima } \\
\hline & Buleji & Hawks bay & Manora & Paradise point & Buleji & Manora & Buleji & Paradise point \\
\hline $\mathrm{J}$ & 85 & 90 & 122 & 127 & 63 & 59 & 127 & 93 \\
\hline $\mathrm{F}$ & 77 & 99 & 96 & 116 & 62 & 46 & 62 & 54 \\
\hline M & 90 & 106 & 104 & 110 & 94 & 80 & 158 & 101 \\
\hline A & 78 & 0 & 99 & 85 & 63 & 67 & 101 & 80 \\
\hline M & 81 & 103 & 106 & 87 & 63 & 42 & 176 & 68 \\
\hline J & 81 & 99 & 103 & 85 & 0 & 67 & 133 & 97 \\
\hline $\mathrm{J}$ & 82 & 110 & 100 & 85 & 0 & 0 & 0 & 0 \\
\hline A & 104 & 0 & 110 & 85 & 94 & 84 & 94 & 127 \\
\hline S & 133 & 0 & 121 & 59 & 44 & 84 & 88 & 0 \\
\hline $\mathrm{O}$ & 111 & 140 & 114 & 70 & 95 & 84 & 76 & 84 \\
\hline $\mathrm{N}$ & 91 & 0 & 113 & 76 & 126 & 101 & 63 & 76 \\
\hline D & 86 & 107 & 93 & 78 & 94 & 126 & 94 & 84 \\
\hline
\end{tabular}


and 1436.9 for alkane $(\mathrm{C}-\mathrm{C}), 1251.7$ for alkane and nitro methane $(\mathrm{C}-\mathrm{N}, \mathrm{N}=\mathrm{O}), 1039.6$ and 933.5 for sulfoxides $(\mathrm{S}=\mathrm{O}), 875.6$ and 721.3 for alkene $(\mathrm{C}=\mathrm{H})$, 671.2 and 532.3 for alkyl halide (C-Cl), 468.7 and 437.8 (C-I) (Fig. 9 and Table 6).

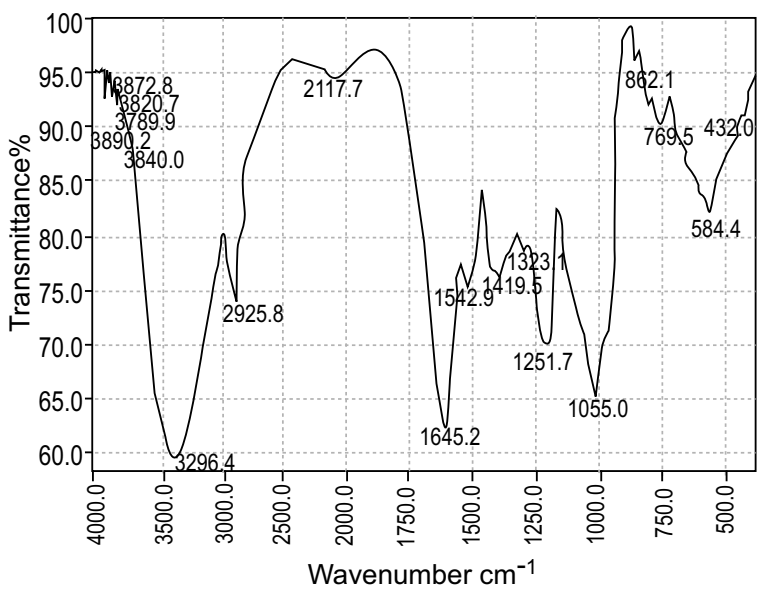

Fig. 8. FTIR spectrum of agar in species of G. corticata.
The agar extracted from G. longissima showed also different peak values at $3793.7,3384.8$ and 2925.8 for functional groups alcohols, amines and alkanes $(\mathrm{O}-\mathrm{H}$, $\mathrm{N}-\mathrm{H}, \mathrm{C}-\mathrm{H}), 2113.8$ for alkynes and nitriles $(\mathrm{C} \equiv \mathrm{C}, \mathrm{C} \equiv \mathrm{N})$, 1639.4 and 1546.8 for carbonyl amide, nitro and aromatic

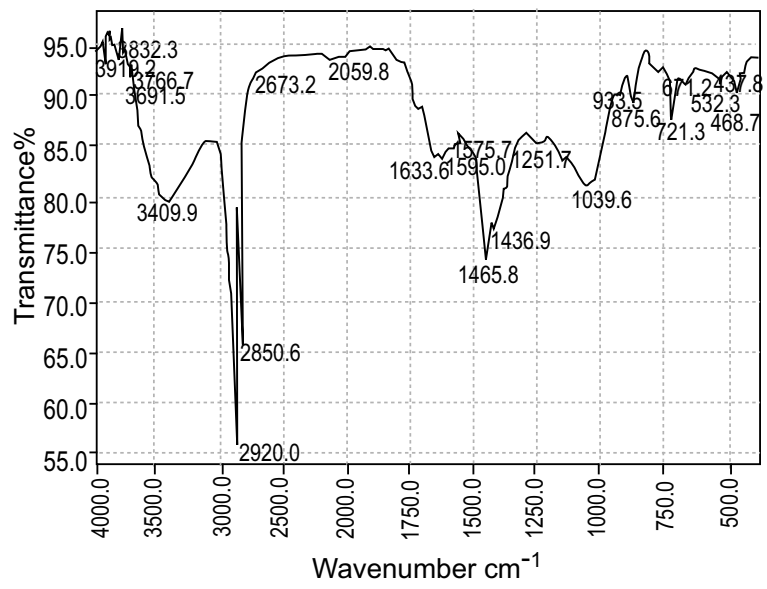

Fig. 9. FTIR spectrum of agar in species of G. dentata.

Table 5. FTIR absorption frequency/(cm), intensity estimation and functional groups of agar extracted from G. corticata

\begin{tabular}{|c|c|c|c|c|c|c|}
\hline IR Frequency & Bond $/(\mathrm{cm})$ & Functional groups & Intensity estimation & $\begin{array}{l}\text { Type of } \\
\text { vibration }\end{array}$ & $\begin{array}{l}\text { Sample IR } \\
\text { frequency/(cm) }\end{array}$ & References \\
\hline $4000-2500$ & $\mathrm{O}-\mathrm{H}, \mathrm{N}-\mathrm{H}, \mathrm{C}-\mathrm{H}$ & $\begin{array}{l}\text { Alcohol, Amine, } \\
\text { Alkane }\end{array}$ & Strong, Sharp & Stretch, Free & $\begin{array}{l}3872.8,3820.7 \\
3890.2,3789.9 \\
3840.0,3396.4 \\
2925.8\end{array}$ & $\begin{array}{l}\text { (Faust, 1997), (Radhika and } \\
\text { Mohaideen, 2015), } \\
\text { (Fernando et al., 2017) }\end{array}$ \\
\hline $2500-2000$ & $\mathrm{C} \equiv \mathrm{C}, \mathrm{C} \equiv \mathrm{N}$ & Alkyne, Nitriles & Medium & Stretch & 2117.7 & (Faust, 1997) \\
\hline $2000-1500$ & $\mathrm{C}=\mathrm{O}, \mathrm{N}=\mathrm{O}, \mathrm{C}=\mathrm{C}$ & $\begin{array}{l}\text { Cabonyl amide, } \\
\text { Nitro methane, } \\
\text { Aromatics }\end{array}$ & $\begin{array}{l}\text { Very weak, } \\
\text { Medium, Strong }\end{array}$ & Stretch & $\begin{array}{l}1645.2 \\
1542.9\end{array}$ & $\begin{array}{l}\text { (Faust, 1997), } \\
\text { (Pavia et al.,2009), (Radhika } \\
\text { and Mohaideen, 2015) }\end{array}$ \\
\hline $1500-1400$ & $\mathrm{C}-\mathrm{C}$ & Alkane & Medium to weak & Stretch & 1419.5 & $\begin{array}{l}\text { (Radhika and Mohaideen, } \\
\text { 2015) }\end{array}$ \\
\hline $1400-1300$ & $\mathrm{C}-\mathrm{N}, \mathrm{N}=\mathrm{O}$ & $\begin{array}{l}\text { Alkane, Nitro } \\
\text { methane }\end{array}$ & Medium & Bending & 1323.1 & $\begin{array}{l}\text { (Pavia et al., 2009), (Radhika } \\
\text { and Mohaideen, 2015) }\end{array}$ \\
\hline $1300-1200$ & $\mathrm{C}-\mathrm{N}$ & Aliphatic amines & Strong & Stretch & 1251.7 & $\begin{array}{l}\text { (Faust, 1997), (Pavia et al., } \\
\text { 2009), (Radhika and } \\
\text { Mohaideen, 2015) }\end{array}$ \\
\hline $1200-1000$ & $\mathrm{~S}=\mathrm{O}$ & Sulfoxides & Strong & Stretch & 1055.0 & (Pavia et al., 2009) \\
\hline $1000-700$ & $\mathrm{C}-\mathrm{H}$ & Alkene & Weak & Bending & 862.1 & (Pavia et al., 2009) \\
\hline $700-500$ & $\mathrm{C}-\mathrm{Cl}$ & Alkyl halide & Strong & Stretch & $\begin{array}{l}769.5 \\
584.4\end{array}$ & $\begin{array}{l}\text { (Faust, 1997), (Pavia et al., } \\
\text { 2009) }\end{array}$ \\
\hline $200-500$ & C-I & Alkyl halide & Strong & Stretch & $\begin{array}{l}432.0 \\
2009)\end{array}$ & (Faust, 1997), (Pavia et al., \\
\hline
\end{tabular}


Table 6. FTIR absorption frequency/(cm), intensity estimation and functional group of agar extracted from G. dentata

\begin{tabular}{|c|c|c|c|c|c|c|}
\hline IR Frequency & Bond/(cm) & Functional groups & Intensity estimation & $\begin{array}{l}\text { Type of } \\
\text { vibration }\end{array}$ & $\begin{array}{l}\text { Sample IR } \\
\text { frequency/(cm) }\end{array}$ & References \\
\hline $4000-2500$ & $\mathrm{O}-\mathrm{H}, \mathrm{N}-\mathrm{H}, \mathrm{C}-\mathrm{H}$ & $\begin{array}{l}\text { Alcohol, Amine, } \\
\text { Alkane }\end{array}$ & Strong, Sharp & Stretch,Free & $\begin{array}{l}3832.3,3917.2 \\
3766.7,3691.5 \\
3409.9,2920.0 \\
2850.6,2673.2\end{array}$ & $\begin{array}{l}\text { (Faust, 1997), (Radhika and } \\
\text { Mohaideen, 2015), } \\
\text { (Fernando et al., 2017) }\end{array}$ \\
\hline $2500-2000$ & $\mathrm{C} \equiv \mathrm{C}, \mathrm{C} \equiv \mathrm{N}$ & Alkyne, Nitriles & Medium & Stretch & 2059.8 & (Faust, 1997) \\
\hline $2000-1500$ & $\mathrm{C}=\mathrm{O}, \mathrm{N}=\mathrm{O}$ & $\begin{array}{l}\text { Cabonyl amide, } \\
\text { Nitro, Aromatic }\end{array}$ & $\begin{array}{l}\text { Very weak, } \\
\text { medium, Strong }\end{array}$ & Stretch & $\begin{array}{l}1633.6,1595 \\
1575.7\end{array}$ & $\begin{array}{l}\text { (Faust, 1997), } \\
\text { (Pavia et al.,2009), } \\
\text { (Radhika and Mohaideen, } \\
\text { 2015) }\end{array}$ \\
\hline $1500-1400$ & $\mathrm{C}-\mathrm{C}$ & Alkane & Medium to weak & Stretch & $1465.8,1436.9$ & $\begin{array}{l}\text { (Radhika and Mohaideen, } \\
\text { 2015) }\end{array}$ \\
\hline $1400-1300$ & $\mathrm{C}-\mathrm{N}, \mathrm{N}=\mathrm{O}$ & $\begin{array}{l}\text { Alkane, Nitro } \\
\text { methane }\end{array}$ & Medium & Bending & 1251.7 & $\begin{array}{l}\text { (Pavia et al., 2009), (Radhika } \\
\text { and Mohaideen, 2015) }\end{array}$ \\
\hline $1200-1000$ & $\mathrm{~S}=\mathrm{O}$ & Sulfoxides & Strong & Stretch & $1039.6,933.5$ & (Pavia et al., 2009) \\
\hline $1000-700$ & $\mathrm{C}-\mathrm{H}$ & Alkene & Weak & Bending & $875.6,721.3$ & (Pavia et al., 2009) \\
\hline $700-500$ & $\mathrm{C}-\mathrm{Cl}$ & Alkyl halide & Strong & Stretch & $671.2,532.3$ & $\begin{array}{l}\text { (Faust, 1997), (Pavia et al., } \\
\text { 2009) }\end{array}$ \\
\hline $200-500$ & C-I & Alkyl halide & Strong & Stretch & $468.7,437.8$ & $\begin{array}{l}\text { (Faust, 1997), (Pavia et al., } \\
\text { 2009) }\end{array}$ \\
\hline
\end{tabular}

$(\mathrm{C}=\mathrm{O}, \mathrm{N}=\mathrm{O}), 1423.4$ for alkane $(\mathrm{C}-\mathrm{C}), 1382.9$ for alkane and nitro methane $(\mathrm{C}-\mathrm{N}, \mathrm{N}=\mathrm{O}), 1261.4$ aliphatic amines $(\mathrm{C}-\mathrm{N}), 1074.3$ for sulfoxides $(\mathrm{S}=\mathrm{O}), 933.5$ and 850.5 for alkene $(\mathrm{C}=\mathrm{H}), 603.7$ for alkyl halide $(\mathrm{C}-\mathrm{Cl}), 488$ and 414.7 for (C-I) (Fig. 10 and Table 7).

The carbohydrate contents in all three species of Gracilaria are uniform and ranged from $22-24 \%$.

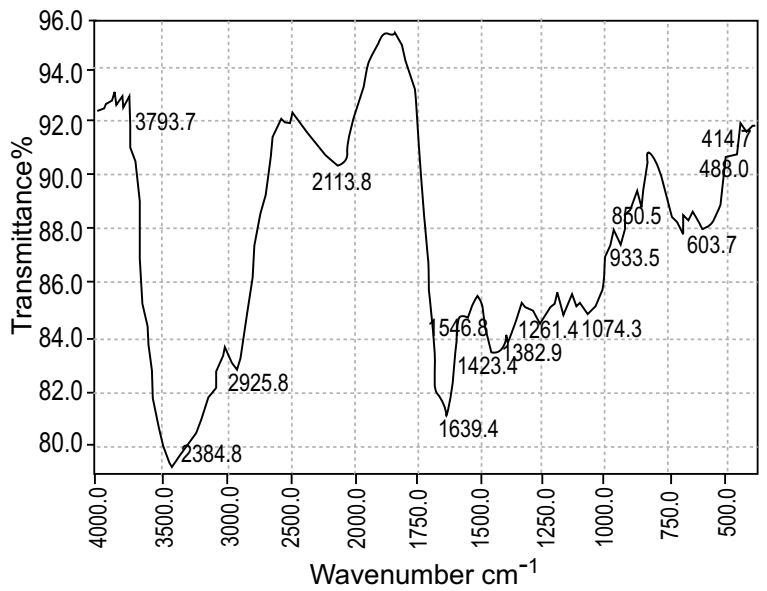

Fig. 10. FTIR spectrum of agar in species of G. longissima.
Mostly the carbohydrate contents in G. corticata, G. dentata and G. longissima were 22\% except in Buleji and Hawks Bay samples of G. corticata carbohydrate that was 24 and $23 \%$ respectively (Fig. 11). The ash contents in all three species of Gracilaria were 20\% except in Buleji coast sample of $G$. dentata that was $30 \%$ (Fig. 12).

The results of two way analysis of variance (ANOVA) of agar of three species G. corticata, G. dentata and

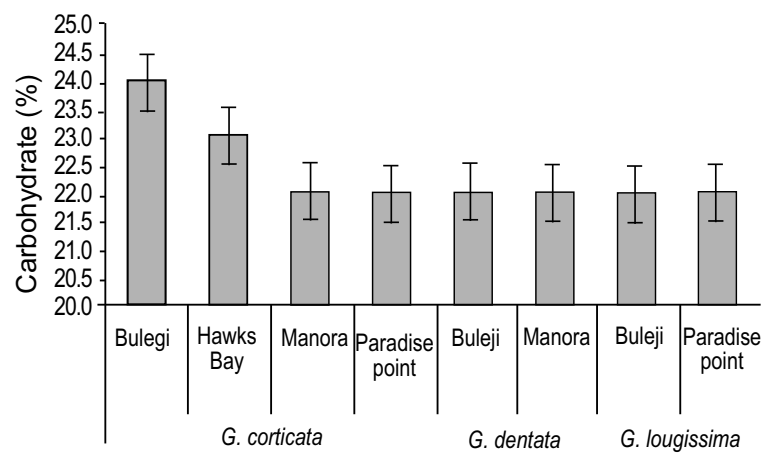

Fig. 11. Carbohydrate content in species of Gracilaria collecting from different sites of Karachi coast. 
Table 7. FTIR absorption frequency/(cm), intensity estimation and functional group of agar extracted from G. longissima

\begin{tabular}{|c|c|c|c|c|c|c|}
\hline IR Frequency & Bond $/(\mathrm{cm})$ & Functional groups & Intensity estimation & $\begin{array}{l}\text { Type of } \\
\text { vibration }\end{array}$ & $\begin{array}{l}\text { Sample IR } \\
\text { frequency/(cm) }\end{array}$ & References \\
\hline $4000-2500$ & $\mathrm{O}-\mathrm{H}, \mathrm{N}-\mathrm{H}, \mathrm{C}-\mathrm{H}$ & $\begin{array}{l}\text { Alcohol, Amine, } \\
\text { Alkane }\end{array}$ & Strong, Sharp & Stretch,Free & $\begin{array}{l}3793.7,3384.8 \\
2925.8\end{array}$ & $\begin{array}{l}\text { (Faust, 1997), (Radhika and } \\
\text { Mohaideen, 2015), } \\
\text { (Fernando et al., 2017) }\end{array}$ \\
\hline $2500-2000$ & $\mathrm{C} \equiv \mathrm{C}, \mathrm{C} \equiv \mathrm{N}$ & Alkyne, Nitriles & Medium & Stretch & 2113.8 & (Faust, 1997) \\
\hline $2000-1500$ & $\mathrm{C}=\mathrm{O}, \mathrm{N}=\mathrm{O}$ & $\begin{array}{l}\text { Cabonyl Amide, } \\
\text { Nitro, Aromatic }\end{array}$ & $\begin{array}{l}\text { Very weak, } \\
\text { medium, Strong }\end{array}$ & Stretch & $\begin{array}{l}1639.4 \\
1546.8\end{array}$ & $\begin{array}{l}\text { (Faust, 1997), (Pavia et al., } \\
\text { 2009), (Radhika and } \\
\text { Mohaideen, 2015) }\end{array}$ \\
\hline $1500-1400$ & $\mathrm{C}-\mathrm{C}$ & Alkane & Medium to Weak & Stretch & 1423.4 & $\begin{array}{l}\text { (Radhika and Mohaideen, } \\
\text { 2015) }\end{array}$ \\
\hline $1400-1300$ & $\mathrm{C}-\mathrm{N}, \mathrm{N}=\mathrm{O}$ & $\begin{array}{l}\text { Alkane, Nitro } \\
\text { methane }\end{array}$ & Medium & Bending & 1382.9 & $\begin{array}{l}\text { (Pavia et al., 2009), (Radhika } \\
\text { and Mohaideen, } 2015\end{array}$ \\
\hline $1300-1200$ & $\mathrm{C}-\mathrm{N}$ & Aliphatic amines & Strong & Stretch & 1261.4 & $\begin{array}{l}\text { (Faust, 1997), (Pavia et al., } \\
\text { 2009), (Radhika and } \\
\text { Mohaideen, } 2015\end{array}$ \\
\hline $1200-1000$ & $\mathrm{~S}=\mathrm{O}$ & Sulfoxides & Strong & Stretch & 1074.3 & (Pavia et al., 2009) \\
\hline $1000-700$ & $\mathrm{C}-\mathrm{H}$ & Alkene & Weak & Bending & $\begin{array}{l}933.5 \\
850.5\end{array}$ & (Pavia et al., 2009) \\
\hline $700-500$ & $\mathrm{C}-\mathrm{Cl}$ & Alkyl halide & Strong & Stretch & 603.7 & $\begin{array}{l}\text { (Faust, 1997), (Pavia et al., } \\
\text { 2009) }\end{array}$ \\
\hline $200-500$ & C-I & Alkyl halide & Strong & Stretch & $\begin{array}{l}488 \\
414.7\end{array}$ & $\begin{array}{l}\text { (Faust, 1997), (Pavia et al., } \\
\text { 2009) }\end{array}$ \\
\hline
\end{tabular}



Fig. 12. Ash content in species of Gracilaria collecting from different sites of Karachi coast.

G. longissima showed that there were highly significant variations observed between sites $(\mathrm{P}<0.001)$, months $(\mathrm{P}<0.05)$ and species $(\mathrm{P}<0.05)$. The differences in species, sites and months in present results reveal that agar content was different in all three studied species at different sites in different times (Table 8). The data for agar concentrations of the three experimental species
Table 8. Analysis of variance (ANOVA) for agar in $G$. corticata, $G$. dentata and $G$. longissima at four different sites of Karachi coast

\begin{tabular}{lllllll}
\hline \hline & \multicolumn{5}{c}{ Analysis of variance } \\
\cline { 2 - 7 } Source & DF & Seq SS & Adj SS & Adj/MS & F & P \\
\hline Month & 11 & 1760.30 & 1760.30 & 160.03 & $1.89^{*}$ & 0.052 \\
Sites & 3 & 1508.77 & 1862.30 & 620.77 & $7.35^{* *}$ & 0.000 \\
Species & 2 & 727.11 & 727.11 & 363.56 & $4.31^{*}$ & 0.017 \\
Error & 79 & 6671.40 & 6671.40 & 84.45 & & \\
\hline Total & 95 & 10667.57 & & & & \\
\hline
\end{tabular}

$*=$ significant at $\mathrm{P}<0.05$ and $* *=$ significant at $\mathrm{P}<0.001$.

used in this study were analyzed to determine the relationship in between agar of the three species of Gracilaria at different sites found. Positive significant correlations were found in agar of $G$. corticata collected from Buleji and Manora ( $\mathrm{r} 2=0.653), G$. dentata collected from Buleji and Manora ( $\mathrm{r} 2-=0.688)$ and G. longissima collected from Buleji and Paradise Point ( $\mathrm{r} 2=0.782$ ). The insignificant correlation was found in between agar, carbohydrate and ash content. 
The present study demonstrated that the yield of agar varied seasonally. The results for yield of agar extracted from the three species of Gracilaria used in this present study were mostly similar to the values reported by Buriyo and Kivaisi (2003). The yield of agar, gelation temperature and gel melting temperature of agar solution of samples used in this study were similar when compared to that of Praiboon et al. (2006). Present study showed greater concentration of agar for $G$. corticata (14-42\%), G. dentata (10-40\%) and G. longissima (13$56 \%$ ) when compared with the previous study from Karachi coast (Qari and Siddiqui, 1993) and Philippine coast for the same genus species (Barros, 2013). The gel relative density $\left(0.79-1.71 \mathrm{~g} / \mathrm{cm}^{3}\right)$ and gel melting temperature $\left(59-140^{\circ} \mathrm{C}\right)$ of $G$. corticata agar in the present study were quite similar to the values (1.08-1.1 $\mathrm{g} / \mathrm{cm}^{3}$ and $91.1-92.5^{\circ} \mathrm{C}$, respectively) reported by Qari and Siddiqui (1993) for the same species, whereas gel viscosity values were lower (39-92 cP) and gel temperature $\left(24-85^{\circ} \mathrm{C}\right)$ and gel strength $\left(94-174 \mathrm{~g} / \mathrm{cm}^{2}\right)$ values were higher than previous study (Qari and Siddiqui, 1993) and two other Philippine species of same genus Gracilaria by (Barros, 2013).

The unusually high gelling temperature observed in this study was partly due to the very viscous solution, which resisted the sinking of glass beads used in the gelling temperature determination (Barros, 2013). High viscosity and melting temperature values indicate a high molecular weight polymer (Whyte and Englar, 1981). The yield of agar of $G$. longissima sample collected from Buleji was high (20-56\%) as compared to G. longissima sample collected from Paradise Point. The agar content of G. longissima in this present study was similar to the values reported in previous study of Sahu and Sahoo (2013) for the same species. The yield of agar was high during winter season. This may be due to high biomass in winter because in this period high nutrient availability and low temperature and light intensity (Qari, 2017). The relative density of $G$. longissima agar solution was almost similar as compared to the results of Qari and Siddiqui (1993).

FTIR is a valuable tool for measuring many chemical constituents in plants and seaweeds to reveal some qualitative aspects regarding the organic compounds (Lammers et al., 2009). The results of FTIR analysis of agar extract showed strong and sharp absorption peaks in the 2673.2-3872.8/cm region (Alcohol, amine, alkane), 1055.0 -1251.7 (Aliphatic amines, Sulfoxides) and 432.0-769.5 (Alkyl halide) region in all agar samples (Fernando et al., 2017; Radhika and Mohaideen, 2015; Pavia et al., 2009; Faust, 1997). The absorbance peak of weak band at $1639.4 / \mathrm{cm}$ represent $\mathrm{C}=\mathrm{C}$ stretching vibration, indicative of the lignin (Kubo and Kadla, 2005; Chatjigakis, 1998). The absorbance peak at $1423.4 / \mathrm{cm}$ representing bending vibration of C-H group indicated the presence of amino acids (Kannan, 2014). The absorbance peak of medium band observed at $2113.8 / \mathrm{cm}$ representing the stretching vibration of $\mathrm{C} \equiv \mathrm{C}$ group, whereas the absorbance peak at $1382.9 / \mathrm{cm}$ representing bending vibration of $\mathrm{C}$-H group indicating the presence of amino acids (Kannan, 2014). The carboxyl and hydroxyl functional groups are mainly found in polysaccharides and are primary constituent of seaweeds found in all studied samples, and can be used in medicine (Kannan, 2014). The other chemical groups which are characteristic of present agar samples are alkyne, nitriles, carbonyl amide, nitro, aromatic alkane, alkane nitro methane and alkene (Radhika and Mohaideen, 2015; Pavia et al., 2009; Faust, 1997). The types of vibration were mostly stretch free, stretch and binding.

The results of extraction of all three studied species $G$. corticata, G. dentata and G. longissima suggested that these edible species are good source of agar that could be used commercially. The functional group alcohols, amines, alkanes, alkynes, nitriles, carbonyl amide, nitro methane, aliphatic amines, sulfoxides, alkene and alkyl halide observed in the experimental seaweeds used in this study as demonstrated in the FTIR analysis indicates that all the experimental seaweeds used in this study could be used medicinally in the treatment of various human diseases. It is therefore suggested that these edible species of seaweeds should be cultivated so as to protect the blue economy or marine resources.

\section{Acknowledgement}

Authors wish to express sincere thanks to Department of Chemistry, University of Karachi and pharmaceutical companies for providing laboratory facilities. Author Rashida Qari is grateful to Higher Education Commission of Pakistan for providing financial support throughout the study period.

Conflict of Interest. The authors declare no conflict of interest. 


\section{References}

A.O.A.C. 1990. Official Methods of Analysis of Association of Official Analytical Chemist. $15^{\text {th }}$ eds., 684 pp., Association Official Analytical Chemists. Arlington, Virginia, USA.

Barros, F.C.N., da Silva, D.C., Sombra, V.G., Maciel, J.C., Feitosa, J.P.A., Freitas, A.L.P., de Paula, R.C.M. 2013. Structural characterization of polysaccharide obtained from red Seaweed Gracilaria caudata (J Agardh). Carbohydrate Polymers, 92: 598-603.

Bixler, H.J., Porse, H. 2010. A decade of change in the seaweed hydrocolloids industry. Journal of Applied Phycology, 23: 321-335.

Buriyo, A.S., Kivaisi, A.K. 2003. Standing stock, agar yield and properties of Gracilaria salicornia harvested along the Tanzanian coast, western Indian Ocean. Journal of Marine Sciences, 2: 171178.

Cynthia Layse F. De Almeida, Heloina De S. Falcão, Gedson R. De M. Lima, Camila De A. Montenegro, Narlize S. Lira, Petrônio F. De Athayde-Filho, Luis C. Rodrigues, Maria de Fátima V. De Souza, José M. Barbosa-Filho, Leônia M. Batista. 2011. Bioactivities from Marine Algae of the Genus Gracilaria. International Journal of Molecular Sciences, 12: 4550-4573.

Dubois, M., Giles, K.A., Hamilton, J.K., Rebors P.A., Smith, F. 1956. Calorimetric method for determination of sugars and related substances. Analytical Chemistry, 28: 350-356.

Faust, B. 1997. Modern chemical techniques: an essential reference for students and teachers. The Royal Society of Chemistry, Unilever, 5: 127-128.

Israel, A., Einav, R., Seckbach, J., 2010. Seaweeds and their Role in Globally Changing Environments. 479 pp., Springer Dordrecht Heidelberg London, New York, USA.

Kannan, S. 2014. FT-IR and EDS analysis of the seaweeds Sargassum wightii (brown algae) and Gracilaria corticata (red algae). International Journal of Current Microbiological Applied Sciences, 3: 341-351.

Kubo, S., Kadla, J.F. 2005. Hydrogen bonding in lignin: a Fourier transform infrared model compound study. Biomacromolecules, 6: 2815 -2821.

Lammers, K., Keil, G.A., Dighton, J. 2009. FTIR study of the changes in carbohydrate chemistry of three
New Jersey Pine Barrens leaf litters during simulated control burning. Soil Biology and Biochemistry, 41: 340-347.

Mohan, J. 2005. Organic Spectroscopy Principles and Applications, $2^{\text {nd }}$ eds., 548 pp., Narosa Publishing House, Daryagani, Delhi, India.

Pavia, D.L., Lampman, G.M., Kriz, G.S. 2009. Introduction to Spectroscopy, $4^{\text {th }}$ edition, $511 \mathrm{pp}$., Brooks/Cole, Cengage Learning.

Praiboon, J., Chirapart, A., Akakabe, Y., Bhumibhaman, O., Kajiwara, T. 2006. Physical and chemical characterization of agar polysaccharides extracted from the Thai and Japanese species of Gracilaria. Science Asia, 1: 11-17.

Qari, R. 2017. An assessment of seaweeds diversity and distribution at the beach of Nathia gali, Karachi, Pakistan. Journal of Marine Science Research Development, 7: 228. doi: 10.4172/2155-9910. 1000228

Qari, R., Siddiqui, S.A. 1993. Biochemical composition and yield of agar from the seaweed Gracilaria corticata of Karachi coast (Pakistan). Marine Research, 2: 77-81.

Radhika, D., Mohaideen, A. 2015. Fourier transform infrared analysis of Ulva lactuca and Gracilaria corticata and their effect on antibacterial activity. Asian Journal of Pharmaceutical Clinical Research, 8: 209-212.

Sahu, N., Sahoo, D. 2013. Study of morphology and agar contents in some important Gracilaria species of Indian coasts. AJPS, 4: 52-59.

Shameel, M., Khan, S.H., Afaq, H.S. 2000. Biodiversity of marine benthic algae along the coast of Balochistan, Pakistan. Pakistan Journal of Marine Biology, 6: 69-100.

Whyte, J.N.C., Englar, J.R. 1980. Chemical composition and quality of agars in the morphotypes of Gracilaria from British Columbia. Botanica Marina, 23: 277-283.

Whyte, J.N.C., Englar, J.R., Saunders, R.G., Lindsay, J.C. 1981. Seasonal variations in the biomass, quantity and quality of agar from the reproductive and vegetative stages of Gracilaria verrucosa type. Botanica Marina, 24: 493-501.

Wilcox, S.J., Bloor, S.J., Hemmingson, J.A., Furneaux, R.H., Nelson, W.A. 2001. The presence of gigartinine in a New Zealand Gracilaria species. Journal of Applied Phycology, 13: 409-413. 